\title{
大気污染の現状を今後の課題
}

\section{1 大気污染の現状}

\section{1 はじめに}

環境庁が昭和 46 年に設置されてから 10 年が経過し た。いわゆる污染者天国であった庁発足前夜の大気污 染が現在一部ではグラフが右下りのカーブを描きはじめ ている.硫黄酸化物対策一つをとつても, 6 次にわたる $\mathrm{K}$ 值規制の強化，燃料使用基準の設定，総量規制の導 入と次々と手がうたれ，1 時間值で $2 \mathrm{ppm}$ 亿も及ぶ濃 度はかげをひそめた。10年前わずか 300 そこそこで大 気污染を測定していた測定局も現在では 1500 をてえ， 地域の現状を刻々記録しつづけている。しかしながら てれで大気污染はもう安心だというには早すぎる，石 油代替エネルギーとして石炭の使用がまたたくまに普 及しつつある.モータリゼーションは急速な勢いで進 んでいる. エネルギー構造の変化や年に 200 万台も増 加している自動車数の伸びが大気污染に与える影響は 必ずしも予断を許さない，乙うした状況を適確にとら えて未然予防の観点から適切な対策を樹てるととが緊
急の課題である.

\section{2 大気污染の測定状況}

科学的な大気行政の基礎資料となる測定データは, 国及び地方公共団体が設㯰する一般環境大気測定局及 び自動車排ガス測定局から報告される。

後者は主として道路を走行する自動車から排出され るガスの測定のため道路沿道に設置されているが，そ れを除いて環境大気の状況は一般局で測定されている。 又一般局の測定項目についてはその設置場所, 備える 測定機器，規模などにより事情がことなるととからす べての項目を同時に測定しているわけではない，その 全国的概況は次のようになっている。（表 1)

\section{3 二酸化硫黄}

良くも悪くも大気污染指標の代表として扱われる 酸化硫黄は，そもそも四日市ぜんそくを発生させた原 因物質であり，乙れを打さえる形でわが国の公害対策 が進められた経緯からもグラフがその軌跡を示すのは 肯けると乙ろである．各測定局に扔いて大部分の物質 が自動測定機によって環境濃度を 1 時間でとに記録し

表 1 測定局設置状況（測定項目別）

\begin{tabular}{|c|c|c|c|c|c|c|c|c|c|c|}
\hline & \multicolumn{2}{|r|}{51} & \multicolumn{2}{|r|}{52} & \multicolumn{2}{|r|}{53} & \multicolumn{2}{|r|}{54} & \multicolumn{2}{|r|}{55} \\
\hline & 市町村 & 測定局 (点) & 市町村 & 測定局 (点) & 市町村 & 測定局 (点) & 市町村 & 測定局 (点) & 市町村 & 測定局 (点) \\
\hline 二酸 化 硫 黄 & 538 & 1,426 & 561 & 1,488 & 586 & 1,535 & 605 & 1,587 & 617 & 1,611 \\
\hline 二酸 化 窒 素 & 435 & 859 & 470 & 968 & 496 & 1,063 & 523 & 1,145 & 546 & 1,206 \\
\hline 一酸 化 窒 素 & 435 & 858 & 470 & 968 & 495 & 1,062 & 523 & 1,145 & 546 & 1,206 \\
\hline 一 酸 化 炭 素 & 158 & 189 & 174 & 206 & 177 & 215 & 182 & 222 & 185 & 224 \\
\hline 光化学オキシダント & 392 & 713 & 413 & 770 & 446 & 847 & 460 & 899 & 485 & 953 \\
\hline 非メタン炭化水素 & 30 & 39 & 50 & 66 & 98 & 129 & 120 & 168 & 162 & 219 \\
\hline 浮遊粒子状物質 & 94 & 177 & 84 & 179 & 92 & 207 & 108 & 231 & 131 & 276 \\
\hline 浮 遊 粉 じ ん & 465 & 1,081 & 510 & 1,169 & 521 & 1,184 & 527 & 1,234 & 527 & 1,216 \\
\hline 降下ばいじん & 377 & 1,695 & 361 & 1,636 & 367 & 1,652 & 382 & 1,603 & 383 & 1,589 \\
\hline
\end{tabular}

* 環境庁大気保全局企画課長 
表 2 二酸化硫黄・環境基準の達成状況

\begin{tabular}{|c|c|c|c|c|c|c|c|c|}
\hline \multirow{2}{*}{ 項目 } & \multicolumn{2}{|c|}{ 有 効 測 定 局を有す る 市 町村 } & \multicolumn{3}{|c|}{ 有 効 } \\
\cline { 2 - 9 } & 総 数 & 達 成 数 & 非達成 数 & 達成率 $(\%)$ & 総 数 & 達 成 数 & 非達 成 数 & 達成率 (\%) \\
\hline 47 & 260 & 64 & 196 & 24.6 & 685 & 227 & 458 & 33.1 \\
\hline 48 & 338 & 140 & 198 & 41.4 & 921 & 427 & 494 & 46.4 \\
\hline 49 & 413 & 252 & 161 & 61.0 & 1,125 & 776 & 349 & 69.0 \\
\hline 50 & 465 & 313 & 152 & 67.3 & 1,238 & 992 & 246 & 80.1 \\
\hline 51 & 522 & 408 & 114 & 78.2 & 1,353 & 1,185 & 168 & 87.6 \\
\hline 52 & 536 & 447 & 89 & 83.4 & 1,415 & 1,316 & 99 & 93.0 \\
\hline 53 & 560 & 498 & 62 & 88.9 & 1,457 & 1,366 & 91 & 93.8 \\
\hline 55 & 590 & 548 & 42 & 92.9 & 1,532 & 1,485 & 47 & 96.9 \\
\hline
\end{tabular}

（注）環境基準を達成している市町村とは，当該地域内のいずれの測定局においてあその測定結果が長期的評価に基つく環境基準 を達成している市町村である。

ているが，その 1 日平均值之, 1 年分を平均した年平 均值を環境基準 ( 1 日平均値 $0.04 \mathrm{ppm}$ 以下, 1 時間値 $0.1 \mathrm{ppm}$ 以下) と対比することにより適否を評価してい る. 年間の測定結果を高い方から並べ 8 番目にくる測 定值をむって評価する方式を長期評価と呼ぶがその達 成数及び達成率は次のようになっている（表 2）

てれを都道府県別にみると，100\%達成しているの が, 35県 ( $74.5 \%$ ) であり, $90 \%$ \%上は11道府県ワー ストは, 東京都の達成率 $83.8 \%$ となっている.

次に，乙れを 1 時間值からみると，1571有効測定局 のうち, 1485局 ( $94.5 \%$ ）は $0.1 \mathrm{ppm}$ 未満であり, 1 時間値で $0.1 \mathrm{ppm}$ を超えた測定局数は 52 局 $(9.7 \%)$ と なっている。

経年的動きをみるため長期間継続して測定を続けて いる全国15の測定局の動向をみると, 42 年度の年平均 值 $0.059 \mathrm{ppm}$ をピークとして年々減少している.（図-1）

又 $54 ， 55$ 年度の 2 年間について有効測定時間以上の 測定を行っている1510局の年平均值の傾向をみると次 のようになる。

\begin{tabular}{|c|r|r|c|}
\hline \multicolumn{2}{|c|}{ 区 分 } & 局 数 & 割合 $(\%)$ \\
\hline 二酸化硫黄濃度が増加している測定局 & 9 & 0.6 \\
\hline " & 横ばいの " & 1,341 & 88.8 \\
\hline " & 減少している " & 160 & 10.6 \\
\hline 合 & 計 & 1,510 & 100 \\
\hline
\end{tabular}

（注） 54 年度と 55 年度との差が年平均值で $0.004 \mathrm{ppm}$ 以内の場 合を「横ばい」とし， 0.005 ppm以上の差がある場合を 「増加」又は「減少」とした。

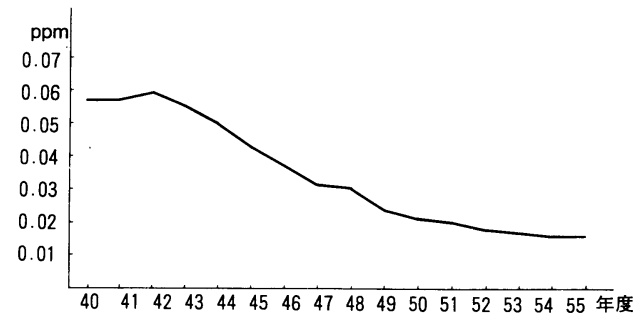

図-1 継続15測定局の二酸化硫黄年平均値の 単純平均值の年度別推移

ちなみに 45 年度あたりをみると, 189 局のうち 49 局ま でが増加傾向になっているが54，55年度では横ばいが 大部分となっている.

污染濃度が高いワースト局についてみると, その評 価の仕方むいくつかあり,イ)年平均値, 口)日平均値の $2 \%$ 除外值, 八)日平均値が $0.04 \mathrm{ppm}$ をてえた日数, 二) 1 時間が $0.1 \mathrm{ppm}$ をてえた時間数などが主なあの であるがそのうちイと八でみると次のようになる。

\section{(イ。表 3 八. 表 4 )}

大勢として二酸化硫黄の污染度が改善されつつある のは明らかではあるが, 大都市の測定局には総量規制 を行ってあ未だ環境基準をクリアーできないとてろが みられる，当該測定局の守備範囲の中にかなり多くの 住民が生活していることを考えると数字の意味すると ころをさらに深く分析する必要があり, 特に大都市地 域の年平均值の経年変化がここ数年全般的に横ばい又 はわずかな減少であるととと合せてな拄注意を怠って はならない。 
表 3 二酸化硫黄年平均値上位測定局

\begin{tabular}{|c|c|c|c|}
\hline 都道府県 & 市 町 村 & 测 定 局 & 年平均值 (ppm) \\
\hline \multirow[t]{2}{*}{ 東 } & 中 央 & 晴 海 & 0.024 \\
\hline & 文 京 & 京 & 0.023 \\
\hline 山 & 備 前 & 沖 浦 & 0.023 \\
\hline 玉 & 草 加 & 市立瀬崎小学校 & 0.022 \\
\hline 京 & 大田 & 糀 谷 & 0.022 \\
\hline 阪 & 堺 & 石 & 0.022 \\
\hline 京 & 目 黒 & 黒 & 0.021 \\
\hline \multirow[t]{2}{*}{ 京 } & 京 都 & 南 & $0.021 \%$ \\
\hline & 舞 鶴 & 西 舞 鶴 & 0.021 \\
\hline & 貝 塚 & 市消防署 & 0.021 \\
\hline & 泉大津 & 泉大津保健所 & $0.021 \%$ \\
\hline
\end{tabular}

（注）※局は長期的評価による環境基準達成局を示す。

\section{4 二酸化窒素}

大気環境からみて 1960 年代が硫黄酸化物の時代な ら 1970 年代は窒素酸化物の時代という人がある. 規 制の強化が進み, 石油の低硫黄化や脱硫装置の設置等 によりかなり効果をあげてきた硫黄酸化物対策と事情が 異なるのが窒素酸化物である.物の燃焼に伴って発生し 又硝酸や窒素肥料の製造工場からの排出，製鉄や火力 発電の過程での発生, さらに自動車や航空機が運行され る場合等人間活動の全般に関連してくるのがこの物質 であり，そのために対策を効果的に実施するにはかなり の努力が必要となってくる. 環境基準は昭和 53 年に改 定され, 1 時間の 1 日平均值が $0.04 \mathrm{ppm}$ から $0.06 \mathrm{ppm}$ までのゾーン内又はそれ以下と定められた. 45 年度か ら継続測定を行っている15局の経年変化は次のように
表 4 日平均值が 0.04 ppm を超えた日数の割合が高 い測定局

\begin{tabular}{|c|c|c|c|c|c|}
\hline $\begin{array}{l}\text { 都道 } \\
\text { 府県 }\end{array}$ & 市町村 & 測定局 & $\begin{array}{l}\text { 有効測定日数に } \\
\text { 対する割合 }(\%) \text { ) }\end{array}$ & $\begin{array}{l}\text { 日数 } \\
(\text { 日) }\end{array}$ & $\begin{array}{r}\text { 年平均値 } \\
(\mathrm{ppm})\end{array}$ \\
\hline 杤 木 & 足尾町 & 町役場 & 6.2 & 22 & 0.014 \\
\hline 京 都 & 舞 鶴 & 西舞鶴 & 5.5 & 14 & 0.021 \\
\hline 鹿児島 & 鹿 屋 & 市役所 & 4.9 & 18 & 0.013 \\
\hline 岡 山 & 備 & 沖 & 3.6 & 13 & 0.023 \\
\hline \multirow[t]{3}{*}{ 東 } & 文 京 & 京 & 3.3 & 12 & 0.023 \\
\hline & 中 央 & 海 & 3.1 & 11 & 0.024 \\
\hline & 黒 & 目 黒 & 2.9 & 10 & 0.021 \\
\hline \multirow[t]{2}{*}{ 北海道 } & 旭 川 & 中 央 & 2.2 & 8 & 0.015 \\
\hline & 札 幌 & センター & 1.9 & 7 & 0.014 \\
\hline 玉 & 草 加 & $\begin{array}{l}\text { 市立瀬崎 } \\
\text { 小学校 }\end{array}$ & 1.9 & 7 & 0.022 \\
\hline
\end{tabular}

\section{なっている（表 5 )}

この表をみると 15 局単純平均で 47 年の $0.02 \mathrm{ppm}$ が 最も低くその後は右上りで横ばいないし上向きで推移 している.

大都市における経年変化をみると, 東京区部, 横浜 市, 大阪市はいずれ屯年平均值 $0.03 \mathrm{ppm}$ (日平均に換 算すると $0.06 \mathrm{ppm}$ ）を上回っており, 札幌市, 京都市 などは，54，55年之上昇傾向を示していることは注意 を要する.

53 年の改定に伴って $0.04 \sim 0.06 \mathrm{ppm}$ のゾーン内地 域として仙台市, 川越市, 等14地域が告示されたが, この地域の動向は 2 地域が増加しているがその他はほ ぼ現状水準を維持している。

年平均值上位測定局は表 6 のようになっているがこ

表 5 二酸化窒素年平均値の経年変化

(単位：ppm)

\begin{tabular}{|c|c|c|c|c|c|c|c|c|c|c|c|c|c|}
\hline 都道府県 & 市町村 & 定 & 45 & 46 & 47 & 48 & 49 & 50 & 51 & 52 & 53 & 54 & 55 \\
\hline 千 葉 & 市 & 国設市原 & .013 & 0.007 & .011 & 0.012 & .011 & 0.012 & 0.011 & 0.014 & & 0.015 & 0.016 \\
\hline \multirow[t]{6}{*}{ 東 京 } & 新 宿 & 国設東京 & 0.034 & 0.027 & 0.019 & & 0.031 & & 0.034 & & & 035 & .028 \\
\hline & 千代田 & 都 广 前 & 0.029 & 0.042 & 0.026 & 0.036 & 0.043 & 0.045 & 0.038 & 0.038 & 0.046 & 0.049 & 0.046 \\
\hline & 江 東 & 城 & 0.020 & 0.015 & 0.024 & 0.035 & 0.037 & 0.035 & 0.031 & 0.034 & 0.042 & 0.044 & 0.039 \\
\hline & 大 田 & 糀 & 0.027 & 0.025 & 0.023 & 0.029 & 0.031 & 0.030 & 0.030 & 0.031 & 33 & 0.032 & 0.031 \\
\hline & 世田谷 & 田 & 0.022 & 0.028 & 0.020 & 0.025 & 0.029 & 0.035 & 0.035 & 0.036 & 0.0 & 0.036 & 0.033 \\
\hline & 板 橋 & & 0.035 & 0.034 & 0.020 & 0.033 & 0.036 & 0.03 & 0.038 & 0.040 & 0.042 & 0.040 & .038 \\
\hline 神奈川 & 川 崎 & 国設川崎 & 0.032 & 0.028 & 0.035 & 0.039 & 0.037 & 0.033 & 0.037 & 0.035 & 0.0 & 0.036 & .033 \\
\hline 愛 知 & 名古屋 & 国設名古屋 & 0.014 & 0.012 & 0.014 & 0.014 & 0.016 & 0.020 & 0.022 & 0.021 & 0.023 & 0.022 & .018 \\
\hline 阪 & 大 阪 & 国設大阪 & 0.025 & 0.022 & 0.034 & 0.037 & 0.038 & 0.038 & 0.039 & 0.035 & 31 & 0.030 & 033 \\
\hline 庫 & 尼 & 国設尼崎 & 0.015 & 18 & & & & & 21 & .025 & 25 & .027 & 028 \\
\hline 根 & 松 & 国設松江 & 0.003 & 0.003 & 0.003 & 0.004 & 0.007 & 0.006 & 0.008 & 0.004 & 0.004 & 0.007 & .004 \\
\hline 山 & 倉 & 国設倉敷 & 0.027 & 0.011 & & 0.012 & 19 & 0.016 & 0.020 & .017 & 013 & 0.013 & .014 \\
\hline 山 & 宇 部 & 国設宇部 & 0.015 & 0.018 & 0.022 & 0.025 & 0.017 & 0.015 & 0.014 & 0.009 & 0.011 & 0.013 & 0.016 \\
\hline 岡 & 北九州 & 国設北九州 & 0.023 & 0.023 & 0.016 & 0.013 & 0.024 & 0.024 & 0.026 & 0.027 & 0.026 & 0.026 & 0.023 \\
\hline \multicolumn{3}{|l|}{15} & 0.022 & 0.021 & 0.020 & 0.025 & 0.027 & 0.026 & 0.027 & 0.026 & 0.028 & 0.028 & 0.027 \\
\hline
\end{tabular}


こにあげられた東京, 大阪, 神奈川は昭和 56 年に窒素 酸化物の総量規制導入を決定した地域である.

表 6 二酸化窒素年平均値の上位測定局

\begin{tabular}{|c|c|c|c|}
\hline 都道府県 & 市 町 村 & 測 定 局 & $\begin{array}{c}\text { 年平均值 } \\
(\mathrm{ppm})\end{array}$ \\
\hline \multirow[t]{3}{*}{ 東 } & 千 代 田 & 都 广 前 & 0.046 \\
\hline & 央 & 晴 海 & 0.042 \\
\hline & 谷 & 渋 谷 & 0.042 \\
\hline \multirow[t]{4}{*}{ 大 } & 阪 & 南稜中学校 & 0.041 \\
\hline & & 扇町中学校 & 0.040 \\
\hline & & 比花区役所 & 0.040 \\
\hline & & 今宮中学校 & 0.040 \\
\hline & 港 & 港 & 0.039 \\
\hline & 江 & 城 東 & 0.039 \\
\hline \multirow[t]{2}{*}{ 神 奈 川 } & 横 & $\begin{array}{l}\text { 鶴 見 区 } \\
\text { 生麦小学校 }\end{array}$ & 0.039 \\
\hline & & $\begin{array}{l}\text { 港 北 区 } \\
\text { 総合庁舎 }\end{array}$ & 0.039 \\
\hline \multirow[t]{2}{*}{ 大 阪 } & 大 & 淀川区役所 & 0.039 \\
\hline & & 堀江小学校 & 0.039 \\
\hline
\end{tabular}

自動車排ガス測定局における二酸化窒素と環境基準 との対応をみると次表のようになる。（表 7 )

表 7 自排局における二酸化窒素の環境基準適合状況

\begin{tabular}{|c|c|c|c|c|c|c|}
\hline \multirow{2}{*}{$\begin{array}{l}\text { 年 度 } \\
\text { 値 } \\
\text { 年間 } 98 \% \text { 值の区分 }\end{array}$} & \multicolumn{2}{|r|}{55} & \multicolumn{2}{|c|}{54} & \multicolumn{2}{|c|}{53} \\
\hline & 局数 & $\begin{array}{l}\text { 割 合 } \\
(\%)\end{array}$ & 局数 & $\begin{array}{l}\text { 割 合 } \\
(\%)\end{array}$ & 局数 & $\begin{array}{l}\text { 割 合 } \\
(\%)\end{array}$ \\
\hline $0.06 \mathrm{ppm}$ を超える & 8 & 38.2 & 64 & & 7 & 40.5 \\
\hline $\begin{array}{l}0.04 \mathrm{p} \\
0.06 \mathrm{p}\end{array}$ & 107 & 45.9 & 112 & 52.6 & 92 & 48.4 \\
\hline $0.04 \mathrm{ppm}$ 末満 & 37 & 15.9 & 37 & 17.4 & 21 & 11.1 \\
\hline वा & 233 & 100.0 & 213 & 100.0 & 190 & 100.0 \\
\hline
\end{tabular}

$0.06 \mathrm{ppm}$ をてえる局数は89局（38.2\%）である. 年平均值で上位の測定局をあげると次のようになって いる.（表 8 )

いずれにしてあ自動車排ガスによる二酸化窒素の污 染を低下させるのには今後排ガス規制適合車への転換 促進, 総合交通対策等においてかなりの努力が必要と なる。
表 8 二酸化窒素年平均值上位測定局（自排局）

\begin{tabular}{|c|c|c|c|}
\hline 都道府県 & 市 町 村 & 測 定 局 & 年平均值 \\
\hline \multirow[t]{4}{*}{ 東 京 } & 板 橋 & 大 & 0.072 \\
\hline & 目 黒 & 人 木 坂 & 0.061 \\
\hline & 杉 並 & 井 & 0.059 \\
\hline & 目 黒 & 大 阪 & 0.056 \\
\hline \multirow[t]{2}{*}{ 大 阪 } & 大 阪 & 今里交差点 & 0.056 \\
\hline & & 住之江交差点 & 0.056 \\
\hline 東 京 & 江 東 & 亀 & 0.055 \\
\hline \multirow[t]{2}{*}{ 大 阪 } & 大 阪 & 北 粉 浜 小 & 0.055 \\
\hline & & 海 老 江 西 小 & 0.055 \\
\hline 東 京 & 千代田 & 比 & 0.054 \\
\hline 神奈川 & 横 浜 & 西区浅間下交差点 & 0.054 \\
\hline
\end{tabular}

\section{5 一酸化炭素}

一酸化炭素は相当部分が自動車排ガスから排出され るが，自動車排ガス測定局 322 局のうち環境基準を達 成しなかったものは 3 測定局（東京品川中原口，上馬 及び横浜の西区浅間下交差点) のみである。一般局に かては 205 測定局がすべて環境基準を達成している.

\section{6 光化学オキシダント}

光化学オキシダントは, 炭化水素と窒素酸化物が光 化学反応を抢ててとによって二次的に生成されるあので あり, $\mathrm{O}_{3}, \mathrm{PAN}$, その他の物質である. 昭和 45 年に東 京都の立正高校に抢いて授業中の生徒が倒れた事件が 光化学オキシダントによるものと推定されているが, アメリカのロスアンゼルスでは, 最近でも高濃度の光 化学スモッグが出現している. 光化学オキシダントが $0.12 \mathrm{ppm}$ をてえてさらに継続すると認められるときに 都道府県において光化学注意報が出されて地域に注意 を呼びかけるが, この注意報の発令は昭和 48 年をピー クとして年々減少しており, 55 年においては冷夏で あったてとも手伝って86件となっている，注意報レべ ルをてえる $0.12 \mathrm{ppm}$ 以上の日数が 12 日以上の測定局 は次の 7 局であった。（表 9 )

また, $0.20 \mathrm{ppm}$ 以上の 1 時間值が出現したのは神 奈川, 埼玉, 大阪，兵庫でありその大部分が 6 月に集 中しており，気象条件等によってはかなり高濃度のも のが出現するポテンシャルを備えていることが分る.

\section{7 浮遊粒子状物質}

大気中に浮遊する粒子状物質は, ばいじん, 粉じん 自動車のまきあげ等多岐にわたるがその中で粒径 $10 \mu$ 
表 $90.12 \mathrm{ppm}$ 以上の 1 時間値が昼間におい て出現した日数の多い測定局

\begin{tabular}{|c|c|c|c|}
\hline 都道府県 & 市町村 & 測 定 局 & $\begin{array}{l}0.12 \mathrm{ppm} \\
\text { 以上の日数 }\end{array}$ \\
\hline 神 奈 川 & 小田原 & 市 役 所 & 17 \\
\hline 大阪 & 大 東 & 市 役 所 & 17 \\
\hline 玉 & 蓮 田 & 蓮田中央小学校 & 14 \\
\hline & 加 須 & 札羽小学校 & 14 \\
\hline & 幸 手 & 町 役 場 & 12 \\
\hline 阪 & 堺 & 若 松 台 局 & 12 \\
\hline & 藤井寺 & 給食センター & 12 \\
\hline
\end{tabular}

以下のものが特に気道や肺胞に達して健康影響を及ぼ すところから環境基準設定をしている，その達成状況 は表10のと抢りであり，他の物質にくらべてかなり悪 く, 達成率は51 年以来 $20 \%$ 台によブまっている. ワー スト10を示すと次のようになる。（表11）

\section{8 降下ばいじん}

大気中に浮遊する物質のうち雨水, 重力などによっ

表10 浮遊粒子状物質環境基準達成状況

\begin{tabular}{|l|crrrrrr|}
\hline & 49 & 50 & 51 & 52 & 53 & 54 & 55 \\
\hline 測 定 局数 & 88 & 139 & 177 & 177 & 201 & 226 & 271 \\
\hline 達 成 局数 & 16 & 22 & 50 & 43 & 45 & 46 & 79 \\
\hline 達成率(\%) & 18.2 & 15.8 & 28.3 & 24.3 & 22.4 & 20.4 & 29.2 \\
\hline
\end{tabular}

表11 浮遊粒子状物質年平均值上位測定局

\begin{tabular}{|c|c|c|c|c|c|}
\hline \multicolumn{2}{|c|}{ 都道府県 } & \multicolumn{2}{|c|}{ 市 町 村 } & \multirow{2}{*}{$\begin{array}{l}\text { 測 定 局 } \\
千 \text { 成 }\end{array}$} & \multirow{2}{*}{$\begin{array}{c}\begin{array}{c}\text { 年平均值 } \\
\left(\mathrm{mg} / \mathrm{m}^{3}\right)\end{array} \\
0.073\end{array}$} \\
\hline 大 & 阪 & 豊 & 中 & & \\
\hline & & 高 & 石 & 取石小学校 & 0.073 \\
\hline & & 大 & 東 & 市 役 所 & 0.068 \\
\hline \multirow[t]{2}{*}{ 愛 } & 知 & 名 古 & 屋 & 国設名古屋 & 0.065 \\
\hline & & 東 & 海 & 名和小学校 & 0.065 \\
\hline 大 & 阪 & 高 & 石 & $\begin{array}{l}\text { 公害監視 } \\
\text { センター }\end{array}$ & 0.065 \\
\hline \multirow[t]{2}{*}{ 兵 } & 庫 & 姫 & 路 & 畑 & 0.065 \\
\hline & & 尼 & 崎 & 城内高校 & 0.065 \\
\hline 愛 & 知 & 碧 & 南 & $\begin{array}{l}\text { 新川町大気 } \\
\text { 污染測定所 }\end{array}$ & 0.063 \\
\hline 広 & 島 & 海 田 & 町 & 海田高校 & 0.063 \\
\hline
\end{tabular}

て降下するばいじん，粉じんがこの中に含まれる。 55 年度において毎月 1 平方粁あたり 20 以上降下し ている地点は 6 地点, $30 \mathrm{t}$ 以上が19地点あるが $30 \mathrm{t}$ 以上 はすべて鹿児島県にあり, 桜島の噴煙によるものと推 定される.

\section{2 今後の課題}

昭和 55 年のデータを中心として大気污染に関わる 主要物質についてその現状をでく大まかに述べ，それ ぞれの物質について若干の問題点についてもふれた。 限られた紙数でああるが, 大気污染の今後の課題につ いて対象をしぼってふれてみたい.

\section{1 石油代替エネルギー（特に石炭について）}

2 次にわたる石油危機により石油代替エネルギーを 求める動きは全世界的な課題となっている.

55 年 IEA 閣僚理事会, ベネチァサミットでの合意 国内での石油代替エネルギー法の制定に伴う代替エネ ルギー供給目標などによって石炭については 65 年度に 2 倍をてえる量が必要とされ, 現在も進んでいる石炭, LNG 等の開発利用がさらに加速される.

大気保全の観点からみると石炭は石油にくらべてか なりダーティであり, 硫黄酸化物, 窒素酸化物で数倍 ばいじんにいたっては 200 倍と発生量が多く, 眝蔵, 運搬による粉じん飛散なども問題よなる。加うるに最 近の状勢から軽質かつ硫黄分の少ない良質原油の確保 が困難になりつつあり，石炭利用に伴う大気環境保全 のための対策が急がれる. 環境基準を維持するために は, 排出基準遵守の徹底, 良質原油の確保, 排煙脱硫 (硝)技術の向上や装置の設置増をはかり，情況によっ ては環境基準をこえている地域へ石炭使用施設の新た な立地は認めないという厳しい方法屯必要となろう。 その他, 石炭排ガス中に含まれる水銀等の重金属など についても調査を行ない住民の健康に悪影響が及ばな いような対応が必要となろう。

\section{2 浮遊粒子状物質}

1.7 に述べたごとく浮遊粒子状物質の環境基準達成 率はかなり低い状況である。そのため本年度から発生 源での防除対策, 環境濃度への寄与率や改善効果等, 多面的に調查検討を行ないその対策を進めるべく努力 を重ねている，発生源は，多様であり工場，事業場な ど産業活動からのもの, 自動車排ガスからの黒煙, 土 壌, 黄砂など自然環境からのものまで含まれており詳 細な寄与度の解明とその対象に応じたきめこまかな対 策が必要となる。 


\section{3 酸性雨問題}

スカンジナビア半島や北米大陸のアメリカ, カナダ 間では国際的公害問題としてかなり大きく取上げられ ているのが酸性雨問題である. 石炭など化石燃料の多 用により酸性度の高い雨が降り, 湖沼や森林等の生態 系に影響を与え魚がすまなくなるという被害も出てい る. 幸いわが国では未だてうした状況に立ちいたって はいないがかつて48〜 50年頃にかなり $\mathrm{pH}$ の高い雨が 関東地域に降り，目の刺激や植物への影響があったて とがある．欧米の情況などにてらして事態が決定的に なってしまってからでは手おくれになる，特に石炭の 消費量も急激な増加が見込まれる時期でああることか ら未然予防の観点からそのメカニズムの解明, 情報の 把握を行って行く必要がある.

\section{4 発がん物質}

わが国でも死因の第一位がガンになるのは時間の問 題とされている，米国の報告によると大気污染を $50 \%$ 減少させれば肺ガンの $25 \%$ すべてのガンを15\%減少さ せうるという試算も出ている. ベンッピレン, ニトロ ピレン等多環芳香族炭化水素やある種の重金属はその 発ガン性について動物実験によって確められつつある. 勿論人体における゙ガン”発生の機序については未だ解 明は進んでおらず，環境性因子の影響についても学説 は分れるところである.しかしながら燃費の価格から， ジーセル車が増加して状況もふまえ発ガン物質の存在 が問題になっているジーゼル排ガスの核散状況や動物 による短期長期の実験によりその実態把握は是非とも 必要であり, その解明が急がれる。 その外, 力ドミウ 么, 弗素, 水銀, 七素などの微量重金属の健康影響も 十分に心してその動きをフォローして行くことによっ て大気環境の監視を続ける必要性は強い.

ここで若干の大気污染による問題点をとりあげてそ の素描をこてろみた。 大気污染像はかなり流動的であ る.いずれにしても国民の健康推持を要諦として適確 な大気污染防止対策と焦点のあった研究を進めて行く ことによってはじめて将来への展望が開けてくるとい えよう.

\section{主 な 既 刊 曹}

\section{下水·廃水・污泥処理ガイドブック}

〈著者〉松本順一郎外 32 名 A 5 判1250頁, 定価13,000円

\section{し尿処理ガイドブック}

〈著者〉岩井重久外50名 A 5 判 760 頁, 定価 9,000円

\section{生活系排水処理ガイドブック}

〈著者〉洞沢勇 外 22 名 A 5 判 480 頁, 定価 8,500円

\begin{tabular}{|l|l|}
\hline 下 水 道 必 携 \\
\hline 〈著者〉野中徹一 外 24 名 \\
B 5 判 650 頁, 定価 7,500 円
\end{tabular}

\section{悪臭防止技術要覧}

〈編著者〉西田耕之助 石黒 辰吉

B 5 判 330 頁, 定価 3,300円

\section{活泥研 究 年 報 '81}

〈著者〉川易 普 外25名 B 5 判 500 頁, 定価 6,000円

\section{公害防止のための計測機器概説}

〈編著者〉柳沢三郎 外 8 名 B 5 判 240 頁, 定価 2,800円

\section{わかり易い公害分析計測基礎講座}

〈著者〉日色和夫 外 5 名 B 5 判 113頁，定価 1,800円

\section{廃棄物処理技術総集編}

〈編著者〉吉田総夫

B 5 判 258頁, 定価 4,200円

-申込み・問合わせ先

環境技術研究会 困書係宛

画550大阪市西区京町堀1-14-25(京二ビル) 。 (06) 443-6445 - 9027 